Vol IV. No.1, September 2019, hlm. 51- 56

Available online at www.jurnal.una.ac.id/indeks/jmp

\title{
UPAYA MENIGKATKAN KEMAMPUAN BERPIKIR KRITIS MATEMATIKA SISWA MELALUI PENDEKATAN OPENENDED
}

\author{
Marliana \\ Guru MTs.PP Daarul Hikmah Sei Alim Hassak \\ Email: marliana.eks@gmail.com
}

\begin{abstract}
This study aims at determining the effort ti improve students' mathematical eritical thinking ability through an Open-Ended Approach in algebraic material at class VII-1 of MTs.PP Daarul Hikmah Sei Alim Hassak in the academic year of 2018/2019. The subject in this study was class VII-1 MTs.PP Daarul Hikmah Sei Alim Hassak, amounting to 40 people. The object of this research was the students' mathematical critical thinking ability in algebraic material at class VII-1 of MTs.PP Daarul Hikmah Sei Alim Hassak in the academic year of 2018/2019. This type of research was PTK. Data needed in this study was obtained from test and observation. The test used was a description test the was given to sstudents after learning through the Open-Ended Approach. Before the test was carried out, the questions were first tested outside the sample to determine the validity and reliability. Data analysis used in this study were: level of students' mastery on subject matter and observation result. From the results of the data analysis above, it can be concluded that the application of learning through an Open-Ended Approach is affectively used on the subject of algebra
\end{abstract}

Keywords:Critical Thinking Ability, Open-Ended Approach, Algebra

\begin{abstract}
Abstrak
Tujuan penelitian ini untuk mengetahui Upaya Meningkatkan Kemampuan Berpikir Kritis Matematika Siswa Melalui Pendekatan Open-Ended Pada Materi Aljabar di Kelas VII-1 MTs.PP Daarul Hikmah Sei Alim Hassak Tahun Ajaran 2018/2019. Subjek dalam penelitian ini adalah siswa kelas VII-1 MTs.PP Daarul Hikmah Sei Alim Hassak yang berjumlah 40 orang. Objek dalam penelitian ini adalah kemampuan berpikir kristis matematika siswa pada materi aljabar di kelas VII-1 MTs .PP Daarul Hikmah Sei Alim Hassak Tahun Ajaran 2018/2019. Jenis penelitian ini adalah PTK. Data yang diperlukan dalam penelitian ini diperoleh dari tes dan observasi. Tes yang digunakan adalah tes uraian yang diberikan kepada siswa setelah pembelajaran melalui Pendekatan OpenEnded dilaksanakan. Sebelum tes dilaksanakan, soal-soal tersebut terlebih dahulu diujikan di luar sampel untuk menentukan validitas dan realibilitasnya. Analisis data yang dipakai dalam penelitian ini adalah : Tingkat Penguasaan Siswa terhadap materi pelajaran dan hasil observasi. Dari hasil analisis data diatas maka dapat disimpulkan bahwa penerapan pembelajaran melalui Pendekatan Open-Ended efektif digunakan pada pokok bahasan aljabar.
\end{abstract}

Kata Kunci : Kemampuan Berpikir Kritis, Pendekatan Open-Ended, Aljabar 
Vol IV. No.1, September 2019, hlm. 51- 56

Available online at www.jurnal.una.ac.id/indeks/jmp

\section{PENDAHULUAN}

Matematika merupakan ilmu universal yang mendasari perkembangan teknologi modern dan memiliki peran penting dalam berbagai disiplin ilmu dan memajukan daya pikir manusia. Ruseffendi (2015: 1) mengatakan bahwa "Matematika bukan hanya alat bantu untuk matematika itu sendiri, tetapi banyak konsepkonsepnya yang sangat diperlukan oleh ilmu lainnya, seperti kimia, fisika, biologi, teknik, dan farmasi." Melihat begitu pentingnya matematika, tidak mengherankan jika matematika dipelajari secara luas dan mendasar mulai sekolah dasar hingga ke jenjang pendidikan menengah yang selalu menjadi mata pelajaran utama selain mata pelajaran lain.

Dalam Undang-Undang Depdiknas (2006: 416) disebutkan bahwa "tujuan diajarkan matematika adalah untuk membekali siswa dengan kemampuan berpikir logis, analitis, sistematis, kritis, dan kreatif serta kemampuan bekerja sama". Salah satu kemampuan berpikir yang paling diperlukan adalah kemampuan berpikir kritis, hal ini juga tercantum di dalam Permendikbud tahun 2016 pembelajaran otentik dalam pembelajaran matematika menekankan pada (1) berorientasi pada proses maupun hasil dalam menyelesaikan masalah (2) aspek penalaran untuk meningkatkan dan mengembangkan keterampilan berpikir logis, kritis, analitis dan kreatif. Kemampuan berpikir kritis juga dimasukkan kedalam strategi pembelajaran maupun perangkat pembelajaran lainnya. Upaya tersebut dilakukan untuk dapat mengembangkan SDM (Sumber Daya Manusia) yang kritis supaya setiap individu dapat menjalani masa depan yang penuh tantangan serta dengan adanya pengembangan kemampuan berpikir kritis ini, diharapkan dapat mencetak generasigenerasi yang mampu bersaing di kancah internasional.

Hal yang sama juga terdapat pada kurikulum yang berlaku di Indonesia saat ini yakni kurikulum 2013, pentingnya kompetensi mengembangkan kreativitas, rasa ingin tahu, kemampuan merumuskan pertanyaan untuk membentuk pikiran kritis untuk hidup cerdas (Permendikbud, 2013). Tujuan tersebut menempatkan berpikir kritis menjadi bagian dari kurikulum matematika yang penting. Lembaga pendidikan telah berupaya meningkatkan kualitas sumber daya manusia dengan mengembangkan sistem pendidikan, struktur kurikulum, dan model pembelajaran yang efektif dan efisien.

Hasil studi TIMSS 2003, Indonesia berada di peringkat ke-35 dari 46 negara peserta dengan skor rata-rata 411 , sedangkan skor ratarata internasional 467 (Zakaria,2014). Hasil studi tahun 2007, Indonesia berada pada peringkat ke-36 dari 49 negara peserta dengan skor rata-rata 397, sedang skor rata-rata internasinal 500 (Zakaria, 2014). Hasil studi TIMSS terbaru pada tahun 2011, Indonesia berada pada di peringkat ke-38 dari 42 negara peserta dengan skor ratarata 386, sedang skor rata-rata internasional 500 (Zakaria, 2014).

Kondisi yang tidak jauh berbeda terlihat dari hasil studi yang 
Vol IV. No.1, September 2019, hlm. 51- 56

Available online at www.jurnal.una.ac.id/indeks/jmp

dilakukan PISA (Programme for Intenational Student Assessment). Hasil studi PISA 2009, Indonesia berada di peringkat ke-61 dari 65 negara peserta dengan skor rata-rata 371, sedang skor rata-rata internasional 500 (OECD, 2014). Hasil studi PISA 2012, Indonesia berada di peringkat ke-64 dari 65 negara peserta dengan skor rata-rata 375, sedang skor rata-rata internasional 500 (OECD, 2014). Studi yang dilakukan TIMSS dan PISA menunjukkan skor yang diraih Indonesia masih di bawah skor ratarata internasional. Selama tiga studi terakhir terlihat bahawa peringkat Indonesia tidak mengalami peningkatan bahkan semakin menurun. Hasil studi TIMSS dan PISA 4 menunjukkan bahwa kemampuan berpikir kritis siswa Indonesia masih tergolong rendah.

Hal yang sama juga terjadi pada siswa di MTs.PP Daarul Hikmah Sei Alim Hassak. Sebagian guru masih menggunakan pendekatan pembelajaran konvensional yaitu dengan berceramah. Guru belum menerapkan model pembelajaran yang dapat membelajarkan siswa secara mandiri dan dapat membangun kemampuan serta pengetahuan mereka secara bertahap. Hal ini terjadi karena siswa masih belum dibiasakan dengan soal-soal maupun pembelajaran yang bertujuan untuk mengasah kemampuan berpikir kritis.

Adanya permasalahan tersebut menuntut peneliti agar melakukan suatu tindakan perbaikan untuk meningkatkan kemampuan berpikir kritis melalui pendekatan Open-Ended.

Pendekatan pembelajaran Open-Ended merupakan pendekatan pembelajaran tipe kooperatif yang dapat melatih kemampuan berpikir kritis siswa. "Pendekatan Open-Ended merupakan pendekatan pembelajaran yang membangun kegiatan interasi antara matematika dan siswa sehingga mengundang siswa untuk menjawab permasalahan dengan cara mereka sendiri" (Sutikno, 2013 :114). Contoh penerapan masalah Open-Ended dalam kegiatan pembelajaran adalah ketika siswa diminta mengembangkan metode, cara atau pendekatan yang berbeda dalam menjawab permasalahan yang diberikan bukan berorientasi pada jawaban (hasil) akhir. Pembelajaran dengan pendekatan Open-Ended diawali dengan memberikan masalah terbuka kepada siswa. Kegiatan pembelajaran harus mengarah dan membawa siswa dalam menjawab masalah dengan banyak cara serta mungkin juga dengan banyak jawaban (yang benar), sehingga merangsang kemampuan intelektual dan pengalaman siswa dalam proses menemukan susuatu yang baru.

Berdasarkan uraian di atas penulis tertarik untuk menerapkan pendekatan Open-Ended dalam upaya meningkatkan kemampuan berpikir kritis matematika siswa pada materi aljabar dikelas VII-1 MTs.PP Daarul Hikmah Sei Alim Hassak, dengan menerapkan pendekatan ini diharapkan dapat menciptakan pembelajaran yang baik serta mampu meningkatkan kemampuan berpikir kritis siswa terhadap pembelajaran matematika. 
Vol IV. No.1, September 2019, hlm. 51- 56

Available online at www.jurnal.una.ac.id/indeks/jmp

\section{METODE}

Penelitian ini adalah penelitian deskritif yaitu menjelaskan atau memaparkan data dari hasil penelitian. Penelitian menggunakan metode Penelitian Tindakan Kelas (PTK) untuk memperbaiki pembelajaran secara bertahap dan terus menerus, selama kegiatan penelitian dilakukan. Populasi dalam penelitian ini adalah seluruh siswa kelas VII-1 MTs.PP Daarul Hikmah Sei Alim Hasak yang berjumlah 40 orang.

Prosedur penelitian dilakukan adalah perencanaan, tindakan, observasi, refleksi sampai siklus III yang dilakukan berhasil. Instrumen pengumpulan data yang digunakan dalam penelitian ini adalah: (1) Lembar Observasi, untuk mengamati proses belajar mengajar selama tindakan diberikan. (2) Tes hasil belajar sebagai data tambahan untuk mengetahui hasil belajar siswa. Dalam penelitian ini sesuai dengan Kriteria Ketuntasan Minimal (KKM) mata pelajaran matematika pada materi aljabar di kelas VII-1 MTs.PP Daarul Hikmah Sei Ali Hassak, siswa dianggap tuntas apabila memperoleh nilai lebih dari atau sama dengan 80. tehnik analisis data yang dilakukan untuk melihat efektivitas satu pembelajaran yaitu teknik penguasaan siswa dan observasi.

\section{HASIL DAN PEMBAHASAN}

Setelah menganalisis hasil tes sebelum tindakan, diketahui bahwa ketuntasan siswa hanya mencapai $30 \%$ atau hanya sekitar 12 orang siswa yang mencapai nilai KKM yang telah ditetapkan, yaitu 80 .

Tabel 4.2.
Hasil Belajar Siswa Kelas VII-1 Sebelum

Tindakan (Pra Siklus)

\begin{tabular}{rc} 
Tindakan (Pra Siklus) \\
\hline RATA - RATA & 76,65 \\
\hline TUNTAS/PERSENTASE & $30 \%$ \\
\hline TIDAK TUNTAS/PERSENTASE & $70 \%$ \\
\hline
\end{tabular}

Sedangkan hasil belajar siswa setelah dilakukan tindakan, mengalami peningkatan.

Tabel 4.3.

Hasil Belajar Siswa Kelas VII-1 Setelah Tindakan (Siklus 1)

\begin{tabular}{rr}
\hline TUNTAS/PERSENTASE & $52,5 \%$ \\
\hline TIDAK TUNTAS/PERSENTASE & $47,5 \%$ \\
\hline
\end{tabular}

Pada tabel 4.3 diatas terlihat ketuntasan hasil belajar siswa secara klasikal adalah $\frac{21}{40} \times 100 \%=52,5 \%$. Sedangkan siswa yang tidak tuntas secara klasikal adalah $\frac{19}{40} \times 100 \%=$ $47,5 \%$

Tabel 4.4.

Hasil Belajar Siswa Kelas VII-1 Setelah Tindakan (Siklus 2)

$\begin{array}{rr}\text { TUNTAS/PERSENTASE } & 62,5 \% \\ \text { TIDAK TUNTAS/PERSENTASE } & 37,5 \%\end{array}$

Pada tabel 4.4 diatas terlihat etuntasan hasil belajar siswa secara klasikal adalah $\frac{25}{40} \times 100 \%=62,5 \%$. Sedangkan siswa yang tidak tuntas secara klasikal adalah $\frac{15}{40} \times 100=$ $37,5 \%$.

Tabel 4.5.

Hasil Belajar Siswa Kelas VII-1 Setelah Tindakan (Siklus 3)

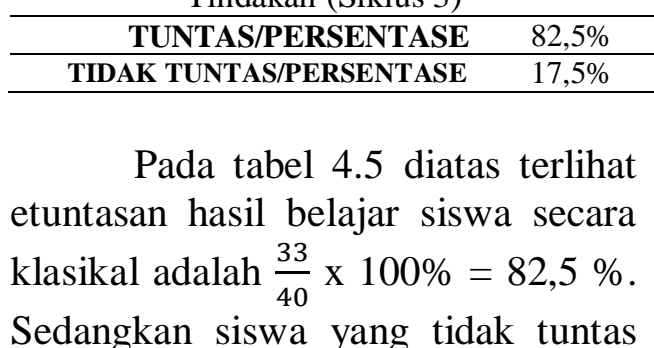
Sedangkan siswa yang tidak tuntas 
Vol IV. No.1, September 2019, hlm. 51- 56

Available online at www.jurnal.una.ac.id/indeks/jmp

secara klasikal adalah $\frac{7}{40} \times 100=$ $17,5 \%$.

Pada penelitian ini subjek yang diteliti berjumlah 40 orang siswa. Setelah ujian terhadap subjek oleh peneliti pada materi aljabar selesai dilaksanakan, maka dibuat gambaran hasil ujian siswa berdasarkan diagram batang berikut ini:

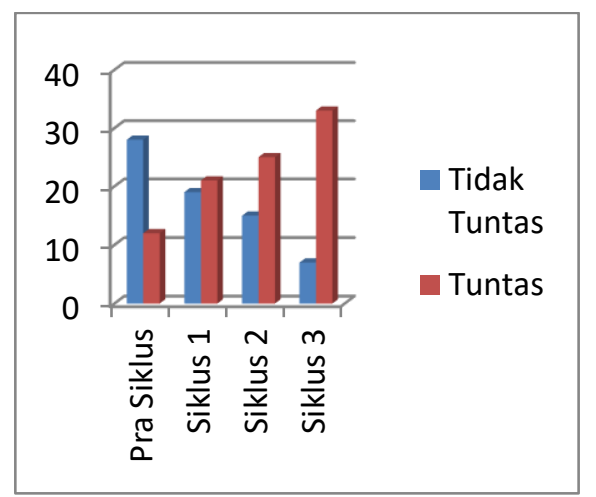

Tabel 4.3. Tingkat Penguasaan Siswa Pada Tes Akhir

\begin{tabular}{|c|c|c|c|}
\hline No & Kategori & $\begin{array}{l}\text { Jumlah } \\
\text { Siswa }\end{array}$ & Persentase \\
\hline 1 & $\begin{array}{l}\text { Sangat } \\
\text { Tinggi }\end{array}$ & 5 Orang & $12,5 \%$ \\
\hline 2 & Tinggi & 10 Orang & $25 \%$ \\
\hline 3 & Sedang & 18 Orang & $45 \%$ \\
\hline 4 & Rendah & 5 Orang & $12,5 \%$ \\
\hline \multirow[t]{2}{*}{5} & $\begin{array}{l}\text { Sangat } \\
\text { Rendah }\end{array}$ & 2 Orang & $5 \%$ \\
\hline & Jumlah & 40 Orang & $100 \%$ \\
\hline
\end{tabular}

Dari tabel di atas dapat diketahui bahwa siswa yang memenuhi tingkat penguasaan paling sedikit sedang adalah sebanyak 33 orang atau $82,5 \%$.

\begin{tabular}{lccc}
\hline Jumlah Skor & 16 & 15 & 18 \\
\hline $\begin{array}{l}\text { Skor } \\
\text { Maksimum }\end{array}$ & 18 & 18 & 18 \\
\hline Nilai & 88,88 & 83,33 & 100 \\
\hline
\end{tabular}

Berdasarkan tabel di atas diperoleh rata - rata nilai hasil observasi adalah 90,74. Dari hasil tersebut dapat disimpulkan bahwa pembelajaran matematika melalui Pendekatan Open-Ended pada pokok bahasan aljabar dalam penelitian ini berjalan baik.

\section{KESIMPULAN DAN SARAN}

\section{Kesimpulan}

Berdasarkan hasil penelitian dan analisis datanya dapat di ambil kesimpulan bahwa:

a. Siklus pertama tidak berhasil.

b. Siklus kedua memiliki peningkatan tetapi belum berhasil karena masih kurang memenuhi syarat ketuntasan belajar (KKM).

c. Siklus ketiga berhasil

Maka dari ketiga siklus di atas dapat disimpulkan bahwa melalui model pembelajaran Pendekatan Open-Ended dapat meningkatkan hasil belajar matematika siswa pada materi aljabar di kelas VII-1 MTs.PP Daarul Hikmah Sei Alim Hassak.

\section{Saran}

Berdasarkan uraian diatas, peneliti memberikan saran antara lain:

1. Sebagai bahan masukkan atau informasi bagi guru matematika tentang kemampuan berpikir kritis matematika siswa pada pokok bahasan aljabar melalui Pendekatan Open-Ended.

2. Sebagai bahan pengetahuan bagi siswa bahwa belajar melalui Pendekatan Open-Ended dapat mengekspresikan idenya dengan 
Vol IV. No.1, September 2019, hlm. 51- 56

Available online at www.jurnal.una.ac.id/indeks/jmp

$$
\begin{array}{llr}
\text { cara mereka } & \text { sendiri } & \text { sehingga } \\
\text { termotivasi } & \text { untuk } & \text { belajar } \\
\text { matematika. } & &
\end{array}
$$

3. Sebagai sumbangan pemikiran guna perbaikan pengajaran disekolah tempat dilaksanakannya penelitian ini khususnya dan sekolah lain pada umumnya.

4. Sebagai bahan pengembangan/tambahan wawasan dan pengalaman bagi peneliti lainnya sebagai calon guru yang nantinya akan menerapkan pembelajaran kepada siswa dalam mempelajari pokok bahasan aljabar.

\section{DAFTAR RUJUKAN}

Russeffendi, (2015). Dasar-Dasar Penelitian Pendidikan dan Bidang Non-Eksakta Lainnya. Bandung: Tarsito

Depdiknas, Standar Isi Matematika, (Badan Standar Nasional Pendidikan, 2006), h.416

Zakaria, 2014 Programme for Intenational Student Assessment).

Sutikno, Sobry. 2013. Belajar Dan Pembelajaran, Upaya Kreatif Dalam Mewujudkan belajar dan Pembelajaran. Lombok:

Holistica

\section{UCAPAN TERIMA KASIH}

Penulis mengucapkan terima kasih kepada dosen pembimbing yaitu Syahriani Sirait,S.Pd,M.Pd selaku dosen pembimbing I dan Elfira Rahmadhani,S.Pd,M.Pd selaku dosen pembimbing II yang telah membimbing dan mengarahkan penulis dalam menyelesaikan jurnal ini. Kemudian penulis juga mengucapkan terima kasih kepada FKIP Asahan Prodi Pendidikan Matematika yang telah memfasilitasi penulis dalam menyelesaikan jurnal ini. 